\title{
OBSTACLES IN IMPLEMENTATION OF THE RIGHT TO WATER
}

\author{
IMPLEMENTAČNÉ ÚSKALIA PRÁVA NA VODU
}

\author{
Kristián ČECHMÁNEK*
}

\section{Introduction}

Basic human rights often tend to be seen as an existence prior to the positive-legal existence. Although such a perspective successfully captures the humanistic axiom of their irrevocability, indivisibility, indecision and inalienability, on the other hand, it encourages legitimate scepticism challenging the human rights category as such. It can be assumed that supporters of the super-legal fundamental human rights do not want to see the subject of their interest only on paper, with constant reminder that the faith in them is the same as faith in unicorns and witches ${ }^{(1)}$, but their ambition is to implement such rights in their feasible form in reality. In other words, they want to ensure that the recipients of such rights have their real performance and, if necessary, enforcement.

In the paper, we will address the third generation of human rights, namely the right to water. Our interest is mainly due to long-term unfulfilled wishes and endeavours to establish such a right in the social reality, despite the positive will and proactive attitude of global players (superpowers, international and multinational organizations, etc.). The aim of the paper is to delimit the boundary between the wanted and the possible, between the normative initiative and the practical obstacles of ensuring the right to water, in the context of public-private cooperation in the provision of water services.

For this purpose, we decided to split the paper into four

Macintyre (2007)

\section{Abstract (EN)}

The paper discusses the right to water as an integral part of a third generation rights in terms of its feasibility. The author tries to point out the need of participation of the private sector in solutions for effective elimination of indisputable humanitarian crisis in the world caused by scarcity of the clean water and most importantly by inadequate access to clean water sources. A long time struggle towards fighting poverty and ensuring basic need for life only by means of official authorities proves that despite indisputable political and normative progress, states consistently fail in meeting demands of implementation. Therefore the author emphasizes the necessity of cooperative action of a private sector and public sector stemming into a participative solution.

\section{Keywords (EN)}

third generation of human rights, right to water, human rights, access to clean water sections. In the first part, we briefly outline the genesis of the third generation of human rights with reference to their intergenerational interdependence and their content diversity. The second part is devoted to water as a value that is a key aspect of the right to water. The subject of this section is Kofi Annan's reasoning, which explicitly stated the reason for accepting the right to water as a fundamental human right. The following section gives us the opportunity to review the legislative and political efforts to secure the right to water, although, as we will see below, despite of clearly formulated goals and standards, they do not yet bring the desired effect into practice. It is the practical implementation of the legislative will that is most interesting to us, and therefore in the last part we define the practical difficulties of implementing the right to water under the controversy over whether the currently preferred public law model of water services can ensure the true content of the right to water.

\section{The Third Generation of Human Rights in abstracto}

It has been more than 40 years since the important French legal (not only) Czech origin theorist Karel Vašák proposed to understand human rights within 3 generations. The first generation of such a division can be understood as the civil and political rights that arose from the International Covenant on

\section{Abstrakt (SK)}

Nasledujúci príspevok pojednáva o práve na vodu ako integrálnej časti tretej generácie ludských práv v súvislosti s možnostami jeho praktickej realizácie. Autor sa vo svojom príspevku snaží zdôraznit’ potrebu účasti súkromného sektora na dosiahnutí efektívneho odstránenia neoddiskutovatel'nej globálnej humanitárnej krízy spočívajúcej v nedostatku čistej vody, ako aj a predovšetkým nedostatočnom prístupe k zdrojom čistej vody. Dlhodobé snahy boja proti svetovej chudobe a nedostatku realizované výlučne verejnoprávnymi aktérmi ukazujú, že aj napriek významnému politickému a normotvornému progresu štáty nad’alej zlyhávajú v reálnej implementácií opatrení na zabezpečenie zlepšenia. Autor vzhladom na uvedené prízvukuje nevyhnutnost' spolupráce medzi verejným a súkromným sektorom ústiacej do spoločného riešenia.

\section{Klưčové slová (SK)}

tretia generácia ludských práv, právo na vodu, ludské práva, prístup k čistej vode 
Civil and Political Rights. The freedom of expression is a typical representative of the catalogue of rights and freedoms of this international treaty. Within the second generation, Vašák identifies economic, social and cultural rights captured primarily in the International Covenant on Economic, Social and Cultural Rights and it is characterized, for example, by the right to work or the right to the fair and satisfactory working conditions ${ }^{(2)}$. The third and last generation are the so-called rights to solidarity whose addressees are collectives rather than individuals. Such rights include, for example, the right to an acceptable environment, right to sustainable development, etc. (3) For the sake of completeness we need to mention that Vašák's theory is often criticized, especially because of the unclear definition of the timeline of generational development of individual human rights, since the author initially considered the acceptance of the Universal Declaration of Human Rights in 1948 (followed by the International Covenant on Civil and Political Rights and the International Covenant on Economic, Social and Cultural Rights of 1966) as the starting point, but later he significantly changed the chronology and as the key moment for the formation of the three-generation system he considered an event, which is philosophically, as well as historically different, and it was the French Revolution in the context of its slogan Freedom, Equality, Fraternity ${ }^{(4)}$. In spite of legitimate criticism, the theory of three-generations of human rights retains a fairly solid position and credibility, which is also evident in its acceptance by the leading scientific journals such as the Human Rights Quarterly. Therefore, we will use the theory of three-generations of human rights as a theoretical framework for the analysis, as we consider it not only widely accepted, but also comprehensive. In other words, the concept of the three-generation system of human rights provides a significant communication advantage, which makes it unnecessary to devote too much space to the description and definitions of individual generations. Contrary, we can immediately move to the subject of our work, the third generation of human rights. But before that we return to the set of three-generations for a moment.

An important aspect of the generation triad is a certain sequence that begins with individually-aimed first generation rights, when individuals are addressed. The rights that arose within the long-term intellectual endeavours of classical liberalism and Locke's tradition were later supplemented by others, influenced by the left-wing thought concept, which provided a certain social standard for the citizen. One thing to emphasize is that the social standard is not an exact category, but rather a reflection on the economic possibilities of a particular society, thus its parameters may vary from country to country. Any subsidy scheme is a typical example of this category. Wellknown American political and legal philosopher Jeremy Waldron attempted to bring a peaceful narrative to the naturally contradictory relationship between the first two generations of human rights and their inevitable collisions (individual vs. collective). He claimed that the second generation of human rights is a prerequisite for genuine implementation of the civil

\footnotetext{
(2) Vasak (1977)

(3) Cornescu (2009)

(4) Jensen (2017)
}

and political freedom coming from the first generation, as living conditions are a determinant of whether or not to enjoy the fruits of free life. Waldron ended his reasoning with a question that we can formulate as follows: "Why it would be good to deal with the freedom of an individual to choose between option $\mathrm{A}$ and $\mathrm{B}$, if such a choice for this person, given the conditions of his life, would not mean anything or would not influence his life in any way?"(5) The described approach of mutual conditionality could certainly be applied to the rights that are the subject of the third generation. There is no need to go far for an example, since environmental issues and sustainable development have just stolen the end of the second decade of the twenty-first century. Thinking analogically, it is worth asking a question: "Can a person live a free life and fully apply fundamental freedoms if he does not have a favourable environment?" Certainly, Waldron would not think so. The correlative logic between individual rights and freedoms, on the one hand, and the quality level of the environment, on the other, is now being profiled as a mainstream of both national and transnational normative practice. Although, we accept the fact that the environmental consequences of the state action are generally cross-border ${ }^{(6)}$ and conceptually it makes no sense to talk about national policies and legislation, we consider meaningful to mention at least some examples from the national practice, which can have, if not crucial then at least inspirational, impact on the development of global environmental legislation and policy.

These days, the European Union is seen as one of the most important environmental players. It is built on the principles of environmental protection and sustainable development. Quoting the article 191 of the Treaty on the Functioning of the EU, the European Union has set itself the following objectives:

- preserving, protecting and improving the quality of the environment,

- protecting human health,

- prudent and rational utilisation of natural resources,

- promoting measures at international level to deal with regional or worldwide environmental problems, and in particular combating climate change ${ }^{(7)}$.

Obviously, the goals are set quite generally, so it will be beneficial to focus on the specific content of the third generation of human rights, which at the same time represents the penetration of all of the European Union's manifested objectives. Let's go to the right to water.

\section{The Third Generation of Human Rights in concreto}

In the previous section, we have briefly outlined the concept of three generations of human rights, while we have drawn our attention to their last generation, represented mainly by the currently extremely popular rights to a favourable environment and sustainable development. As we have already indicated at the end of the previous section, we intend to examine one of

\footnotetext{
(5) Waldron (1993)

(6) Sands (2003)

(7) Treaty on the Functioning of the EU. article. 191.
} 
the most discussed rights of the present - the right to water. At the same time we would like to add that the right to water is still not a fully established right, and there is a lot of controversy about its nature. The tendencies favouring water as a subject of rights are based on the nature of water as a sine qua non condition for life ${ }^{(8)}$. Suitable for this approach is the Kofi Annan's statement that: "Access to safe water is a fundamental human need, and therefore a fundamental human right." According to available literature, the contaminated water caused $80 \%$ of all world diseases by $2007^{(9)}$. However, water is not only a significant biological value but also a cultural value. As an example we can mention the ancient philosophers according to who water was "the foundation of being" (Táles) or a metaphor for constant change - the flow (Heraclitus of Ephesus), or the religious symbol of Christian or Hindu for purification ${ }^{(10)}$. Esotericism and mysticism are not less important cultural impetus, where the value of water is irreplaceable. The renowned Nordic mythology gives the water the magical qualities that have been experienced by Odin himself, sacrificing one eye for a sip from Mimi's well. Water from under Yggdrasil provided Odin with absolute wisdom ${ }^{(11)}$. From the aforementioned it is quite clear that water is a significant civilization value. In the following text, we will outline the political-legal basis of the right to water, as well as the problems that the establishment of the right to water may currently face.

\section{Right to Water: Normative Basis}

A norm establishes what is supposed to be, an ideal reality, which it is desirable to approach and to achieve. The normative language is basically the language of the evaluator, which determines what is good and what is not good. For example, if we say that water should be the subject of fundamental rights, we are implicitly saying that it is both right and good. In the case of an institutional provision of a given standard, its violation, non-compliance or refusal would give the enforcing power the right to redress and secure such a right for its addressees. However, the adoption of a standard does not guarantee its application and does not change social reality. Global players are well aware that a number of deaths, illnesses and unfulfilled or wasted human potentials are due to a lack of clean water, which is a determinant of life per se. However, current normative development has stopped somewhere halfway between the intention and implementation. It is obvious, and quite often heard, that we are experiencing a global drinking water crisis, especially in the inadequate access to water resource caused by various factors, especially power relations and specific decisions by national governments ${ }^{(12)}$. As it is a global problem, solvable only by a broad consensus, a collective solution is needed. The journey to the right to water began long time ago, but within the context of the human rights agenda only during the twentieth century, for example, in Articles 6, 7 and 10 of the

\footnotetext{
(8) Guyton, Hall (2006)

(9) Barlow (2007)

(10) Čechmánek (2015)

(11) Gaiman (2018)

(12) Grönwall (2008)
}

document "Convention on the law of the non-navigational uses of international watercourses" from 1997. The provisions of Art. 4, para. 2 of the Protocol on Water and Health to the Convention on the Protection and Utilization of Transboundary Watercourses and International Lakes from 1992 may serve as another example. The Stockholm Declaration, which deals with the development and sustainability of the environment, highlights, among other things, the fundamental right of man to adequate living conditions enabling a dignified life, and also draws attention to the sustainable development of natural resources ${ }^{(13)}$. It is not our goal to thoroughly analyse all political and legal documents dealing with water as a possible subject of rights. The purpose of the previous lines is to point out that the lack of access to water, the notion on the importance of water for human life, and the desire to establish a form of human rights that provide real access to water goes deeply into the history. Perhaps, before moving into the present, it would be appropriate to mention the significance of the Dublin Principles and the Rio de Janeiro Conference, both of which enunciated environmental rights, but looking back the "legislative" enthusiasm may not be exaggerated as none of these events helped to formulate an unambiguous and legally binding framework that would guide the content of the right to water and how to obtain it.

This happened only in 2005, when the Water and Health Protocol came into force, considered the first wide international legal mechanism aimed at preventing, controlling and reducing water-borne illnesses. The purpose of the Protocol is, among others, to protect human health and to improve living conditions through better water management ${ }^{(14)}$. Another important moment was the adoption of a resolution recognizing access to clean water and sanitation as a human right at the UN platform on the occasion of the $64^{\text {th }}$ General Assembly. The resolution includes: "calls for states and international organizations to provide funding, build capacities and transfer technologies, especially to developing countries, and make every effort to ensure accessible, safe, clean and affordable drinking water and sanitation for all." (15)

Although the establishment of the right to water at the international level is a significant progress in international law, it is still only perceived as a political consensus. The effectiveness of a standard, i.e. its application potency, is one of the most basic attributes of standards. It is therefore symptomatic that authors of the standard seek its fulfilment in practice. However, this is extremely demanding in terms of water distribution, not only in an international context, where there is a constant problem with the enforcement of international standards, but also in the context of national solutions. In the next section, we will try to identify the key issue of implementing the right to water in its application practice and outline a possible solution to the current situation. 


\section{Right to Water: Application Practice}

To formulate a normative goal is one thing, but another thing is to implement the content of such a standard. Nowadays, few people are likely to oppose the noble idea of the universality of humanism and human dignity. This is related to people's access to water. As mentioned in the previous sections, it is hard to implement any other rights without such an approach. So how to realize the fundamental human right to water? Activism is often confined to the question of whether water availability should be universal and whether water is to be subject to human rights by leaving the solutions to other subjects.

As the right to water should be a human right based on the concept of universality and the over-positive nature of fundamental human rights, such entity will be state. The state is, by default, the guarantor of respect for and implementation of fundamental human rights. Contrary to the first generation rights, whose implementation and protection is largely due to the non-interference of the state power in the sphere of citizens' freedom, the exercise of the right to water requires the opposite approach - the institutional involvement of the state $^{(16)}$. Such an obligation may arise from the national legislation or case law. For example the decisions by the Argentinian courts, which had the duty of state authorities to ensure a minimum amount of water (50 to 100 litres per person per day) to residents, regardless of their ability to pay for such service ${ }^{(17)}$. This option prefers the universal access to water over the private interests of the private water sector. It is logical, since the right to do business may enter into a collision with the right to water. The fight against the so-called water privatization is not unknown also in the domestic environment. In the European perspective, the Right2water initiative (the first successful European petition signed by more than 1.8 million EU citizens) is known for its attempt to exempt water from the single market rules in addition to the universal access to water.

Apart from the fact that the exemption requirement was already outlined by the Directive 2000/60 / EC of the European Parliament and of the Council (in the preamble, point 1 , it stressed that water is not a commercial product but rather a heritage that needs to be protected and handled appropriately $\left.{ }^{(18)}\right)$, Right2water has repeatedly launched the debate on whether it is correct to let private sector and water installations participating on the water management, or exclude them entirely arguing that citizens should be able to "pay reasonable fees that reflect their needs, not the needs of distribution company shareholders." (19) Although this has not been fully implemented, the European Union has adopted "a commitment to promote the right of access to water in development policies, where public-private partnerships have been preferred so far."(20) The biggest concern about the private sector involved in the water sector is the

\footnotetext{
(16) Singh (2016)

(17) Giupponi, Pazz (2015)

(18) Directive 2000/60/EC of the European Parliament and of the Council of 23 October 2000 establishing a framework for Community action in the field of water policy

(19) Euractiv

(20) Ibid.
}

increase in prices and the consequent unavailability of water for the poor ${ }^{(21)}$.

On the other hand, it is important to note that private sector participation in water services and distribution networks does not yet mean water privatization. In addition, according to several studies, the participation of private powers in the water economy has been beneficial in terms of the quality, purity and availability of water ${ }^{(22)}$. This is due to the fact that an ideal case where the state has exclusive rights and obligations to water services or water distribution networks also entails certain financial demands, but these are, according to calculations, for the state unbearable without private sector participation. This can be seen, for example, in Argentina, where after the involvement of private companies in water management, child mortality has decreased by up to 8\% over the period 1991-1997. But let's have a look at the world's strongest economy - the USA. An aging piping system poses a threat to the quality and purity of the water as well as to the loss during its distribution. In cities, losses are around 15\%, but in geologically unstable regions, this figure rises to $50 \%$. The necessary investments for maintenance of the US water networks were planned to require about trillion dollars in the previous decade ${ }^{(23)}$. Unlike private companies, states cannot afford such investments and ultimately by the complete removal of private individuals, access to real water is also limited. In such situation, it is not a very moral dilemma, since it is not possible to provide water to everyone, for free and in adequate quality. The distribution of water with the help of the private sector, which bears a significant part of the investment, seems to be a compromise. On the other hand, this is offset by water charges. In the current situation, it is obviously impossible to ensure universal right to water. Such a possibility remains the domain of only some countries.

\section{Conclusions}

The right to water is not only logical but also long-term initiative of the world leaders, which aims at delivering affordable water for all in order to ensure the basic needs for a dignified life. The long-term normative efforts, however, face a number of practical obstacles, of which the most significant are probably the costs of ensuring the real operation of such a right. The availability of water is inevitably tied to the construction/ maintenance of water networks, what is typically too financially demanding for individual states. This is also related to the legitimate requirement to exclude the private sector from doing business in the water sector in order to prevent commercialization and the related inaccessibility of water for people in need. As it can be observed in some regions, the private sector is so far indispensable for securing water supplies, since in synergy with state institutions, they can provide people with water in a more efficient way than the states themselves could do.

\footnotetext{
(21) Labonte, Schrecker, Sanders, Meeus (2004)

(22) Marin (2009)

(23) Water Infrastructure Now
} 


\section{References}

1. BARLOW, M. 2007. Blue Covenant: The Global Water Crisis and the Coming Battle for the Right to Water, Toronto: McCLELLAND \& STEWART. pp. 196 . eISBN 978-1-55199-157-3.

2. CORNESCU, A. V. 2009. The Generations of Human's Rights. In: Dny práva. Brno: Masaryk University. pp. 2482-2492. ISBN 978-80-210-4990-1.

3. ČECHMÁNEK, K. 2015. Právo na vodu v politickom a právnom kontexte. In: Justičná revue. no. 2. pp. 156-168. ISSN 1335-6461.

4. EURACTIV. Právo na vodu: predvolebná téma. [online].[Cit. 28.05.2019]. Available at: https://euractiv.sk/section/voda/news/ pravo-na-vodu-uspokojiva-odpoved-022288/.

5. GAIMAN, N. 2018. Severská mytológia. Bratislava: Slovart. pp.256. ISBN 978-80-556-2979-7.

6. GIUPPONI, M. B. O., PAZ, M. C. 2015. The Implementation of the Human Right to Water in Argentina and Colombia. In: Anuario Mexicano de Derecho Internacional. no. 15. pp. 323-352.

7. GRÖNWALL, J. T. 2008. Access to water: Rights, obligations and the Bangalore situation. Linköping: Linköping University. pp. 429. ISBN 978-91-7393-870-9.

8. GUYTON, A. C., HALL, J. E. 2006. Textbook of Medical Physiology. Philadelphia: Elsevier Saunders. pp. 1116. ISBN 0-7216-0240-1.

9. JENSEN, S. L. B. Putting to rest the Three Generations Theory of Human Rights. In: OpenGlobal Rights [online]. 15.11.2017 [cit. 27.05.2019]. Available at: https://www.openglobalrights.org/putting-to-rest-the-three-generations-theory-of-human-rights/.

10. LABONTE, R., SCHRECKER, T., SANDERS, D., MEEUS, W. 2004. Fatal Indifference: The G8, Africa and Global Health. Cape Town: University of Cape Town Press, pp.400. ISBN 1-91971-384-0.

11. MACINTYRE, A. 2007. After Virtue. Notre Dame: University of Notre Dame Press. pp. 286. ISBN-13 978-0268035044.
12. MARIN, P. 2009. Public- Private Partnerships for Urban Water Utilities: A Review of Experiences in Developing Countries. Washington: The International Bank for Reconstruction and Development, pp.191. ISBN 978-0-8213-7956-1.

13. SANDS, P. 2003. Principles of International Environmental Law. New York: Cambridge University Press. pp. 1246. ISBN-13 9780-511-07684-8.

14. SINGH, N. 2016. Translating the Human Rights to Water into Reality. In: The Human Right to Water: From Concept to Reality. Springer, pp.238. ISBN 978-3-319-40285-7.

15. ÚRAD VEREJNÉHO ZDRAVOTNÍCTVA SLOVENSKEJ REPUBLIKY (Public Health Authority of the Slovak Republic). Ludské právo na prístup k čistej vode a sanitácii. [online]. [Cit. 28.05.2019]. Available at: http://www.uvzsr.sk/index.php?option=com_con tent\&view=article\&id=978:udske-pravo-na-pristup-knistejvode-a-sanitacii\&catid=86: pitna-voda\&Itemid=92.

16. VASAK, K. 1977. A 30-year struggle. In: The Unesco Courier, no. 11. pp. 28-29, 32.

17. WALDRON, J. 1993. Liberal Rights: Collected Papers 1981-1991. New York: Cambridge University Press. pp. 496. ISBN-13: 9780521436175

18. WATER INFRASTRUCTURE NOW. [online]. [Cit. 15.05.2019]. Available at: http://www.win-water.org/reports/winow.pdf.

\section{Contact address/ Kontaktná adresa}

Mgr. Kristián Čechmánek, PhD.

Department of Law

Faculty of European Studies and Regional Development

Slovak University of Agriculture in Nitra,

Tr. A. Hlinku 2, 94976 Nitra

email: k.cechmanek@gmail.com 